\title{
Dermatomyositis Associated with Lung Neuroendocrine Carcinoma
}

\author{
Reina Takashima ${ }^{1}$, Kazufumi Takamatsu ${ }^{1}$, Yutaka Shinkawa ${ }^{2}$, Masato Yagita ${ }^{2}$, \\ Motonari Fukui ${ }^{1}$ and Masaaki Fujita ${ }^{2}$
}

\begin{abstract}
Dermatomyositis is associated with various types of malignancy. However, the association of dermatomyositis with lung neuroendocrine carcinoma is rare. We herein report a case of dermatomyositis with lung neuroendocrine carcinoma.
\end{abstract}

Key words: dermatomyositis, paraneoplastic syndrome, neuroendocrine carcinoma, lung cancer

(Intern Med 56: 719-724, 2017)

(DOI: 10.2169/internalmedicine.56.7768)

\section{Introduction}

Dermatomyositis is associated with various types of malignancy (1-5), and the spectrum of associated malignancies parallels that observed in the general population, varying with ethnicity and geographic region. Breast, lung, and colorectal cancers are malignancies commonly associated with dermatomyositis in Western countries (1-4), whereas gastric cancer is the malignancy most commonly associated with dermatomyositis in Japan, followed by colon, ovarian, lung, thymic, and pancreatic cancers (5). The association of nasopharyngeal malignancy with dermatomyositis is also well described in Asian countries (6-9). However, the association of dermatomyositis with lung neuroendocrine carcinoma is rare. We herein report a case of dermatomyositis with lung neuroendocrine carcinoma. In addition, to analyze the published evidence, we conducted a systemic review of the Medline database through PubMed.

\section{Case Report}

A 75-year-old man was admitted to Kitano Hospital with muscle weakness, muscle pain, rash, arthralgia, severe dysphagia, and a fever. He had a one-month history of rash on the extensor surfaces of the metacarpophalangeal and interphalangeal joints on both hands and on the eyelids, and a two-week history of symmetrical proximal muscle weakness in the upper and lower limbs and poor oral intake. He had been smoking 40 cigarettes a day for 40 years. He was a precision polishing worker, with no history of exposure to either radiation or industrial chemicals. A physical examination revealed cutaneous manifestations of Gottron's sign and heliotrope rash. Medical research council (MRC) scale for muscle strength was grade 3 for the upper and lower limb muscles. Laboratory tests showed the following: creatine kinase (CK), 15,242 IU/L (normal, <248 IU/L); myoglobin, $2,504 \mathrm{ng} / \mathrm{mL}$ (normal, $<73 \mathrm{ng} / \mathrm{mL}$ ); aldolase, $31.6 \mathrm{U} / \mathrm{mL}$ (normal, $<4.9 \mathrm{U} / \mathrm{ml}$ ); C-reactive protein, $2.53 \mathrm{mg} / \mathrm{dL}$ (nor$\mathrm{mal},<0.14 \mathrm{mg} / \mathrm{dL}$ ); and erythrocyte sedimentation rate, 42 $\mathrm{mm} / \mathrm{h}$ (normal, $<20 \mathrm{~mm} / \mathrm{h}$ ). The results for anti-nuclear antibody were positive $(1: 80$, speckled) with the indirect immunofluorescence test (normal, <1:40). Anti-transcriptional intermediary factor $1-\gamma$ antibody was positive, but negative results were obtained for antibodies to aminoacyl-tRNA synthetases (Jo-1, PL-7, PL-12, OJ, and EJ), signal recognition particle (SRP), melanoma differentiation-associated protein 5 (MDA-5), Ku, and Mi-2. Magnetic resonance imaging showed signal hyperintensities on short T1 inversion recovery images in the deltoid, biceps, triceps, trapezius, infraspinatus, and supraspinatus muscles. Electromyogram and muscle biopsy were not performed. Computed tomography revealed no evidence of interstitial pneumonia. Dermatomyositis was diagnosed based on the criteria of Bohan and Peter

${ }^{1}$ Respiratory Disease Center, Division of Respiratory Medicine, The Tazuke-Kofukai Medical Research Institute, Kitano Hospital, Japan and ${ }^{2}$ Department of Clinical Immunology and Rheumatology, The Tazuke-Kofukai Medical Research Institute, Kitano Hospital, Japan Received for publication May 26, 2016; Accepted for publication July 8, 2016 Correspondence to Dr. Masaaki Fujita, ms-fujita@kitano-hp.or.jp 

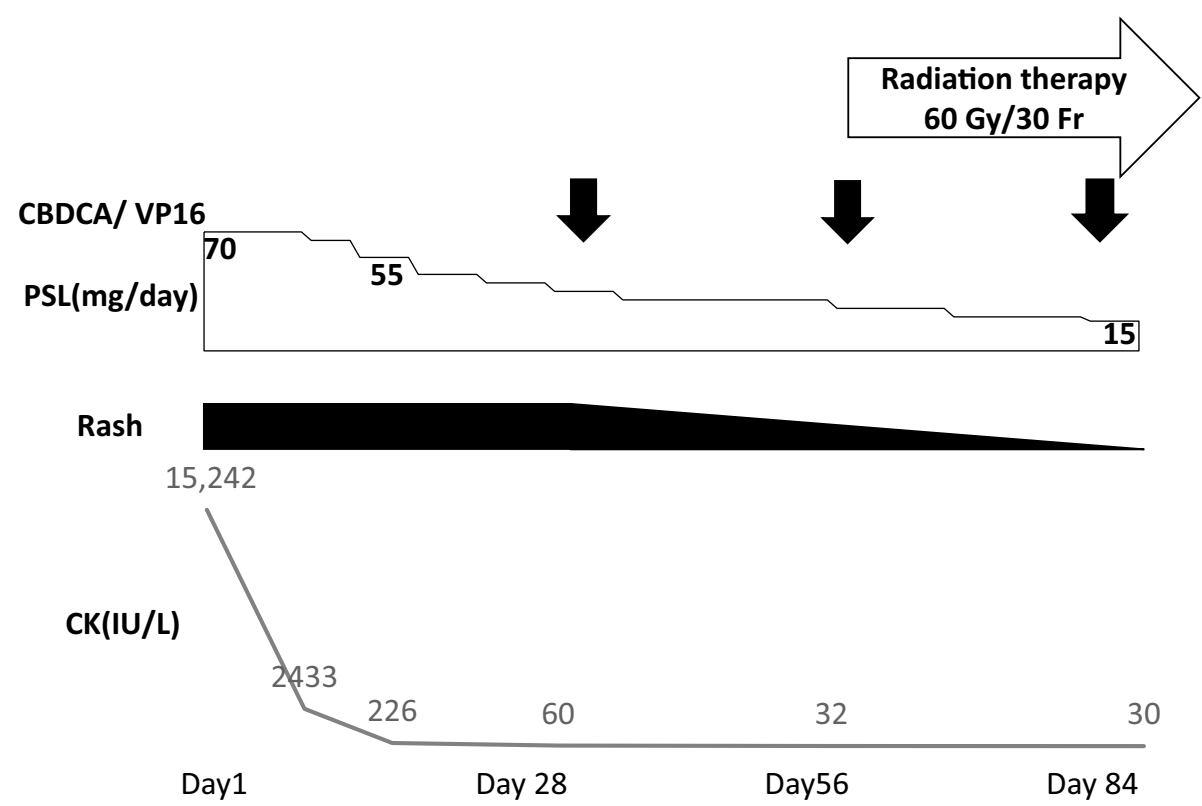

Figure 1. The patient's clinical course.

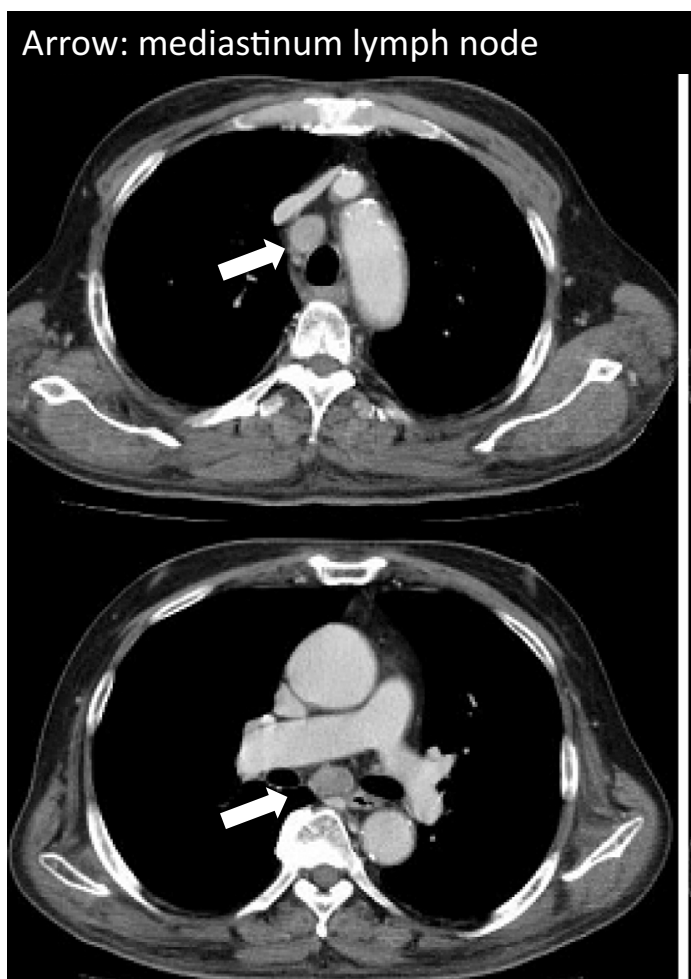

Day1

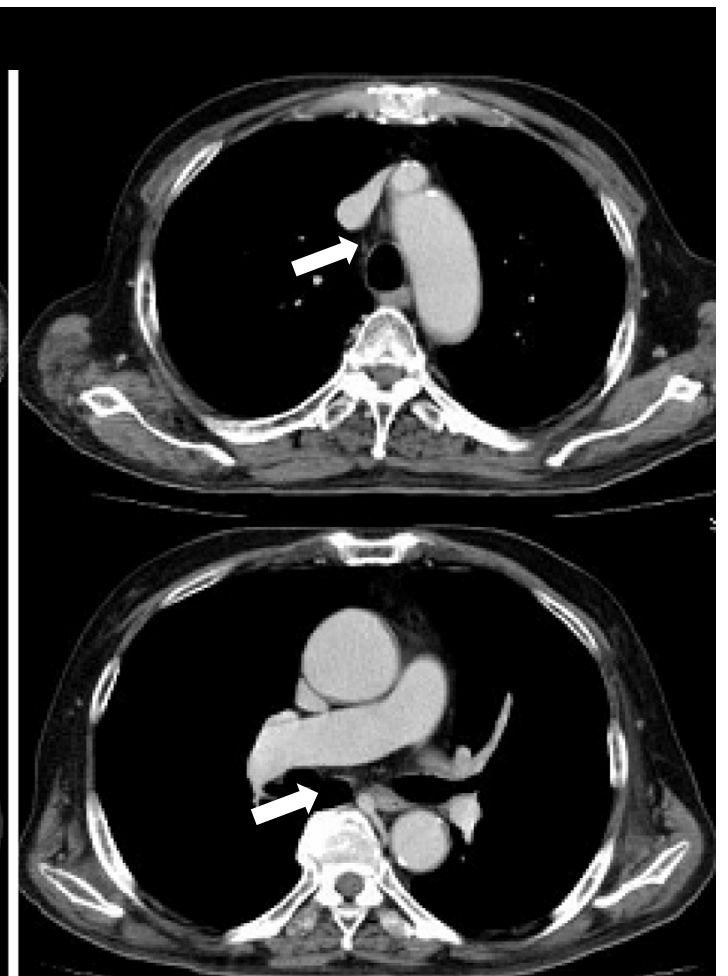

Day 56

Figure 2. Chest computed tomography.

(probable; symmetric proximal muscle weakness, elevation of serum skeletal muscle enzymes, and skin rash) $(10,11)$. Oral prednisolone (PSL) at $70 \mathrm{mg} /$ day $(1 \mathrm{mg} / \mathrm{kg} /$ day $)$ was initiated and elicited a prompt response. The patient's clinical course is shown in Fig. 1. The symptoms such as cutaneous manifestations, muscle weakness, and dysphagia, as well as the laboratory data, all promptly improved. The MRC scale for muscle strength became grade 4 for the upper and lower limb muscles. Notably, administration of PSL improved the patient's oral intake. Muscle enzyme levels normalized (e.g. CK, 226 IU/L; normal, <248 IU/L) by Day 14.

The possibility of malignancy was examined during the diagnosis and treatment of dermatomyositis. Computed tomography revealed a nodule, $13 \mathrm{~mm}$ in diameter, in the upper lobe of the right lung and lymph node swelling in the left lower neck and right mediastinum (Fig. 2). No evidence of other primary tumors or metastases was seen in the stom- 


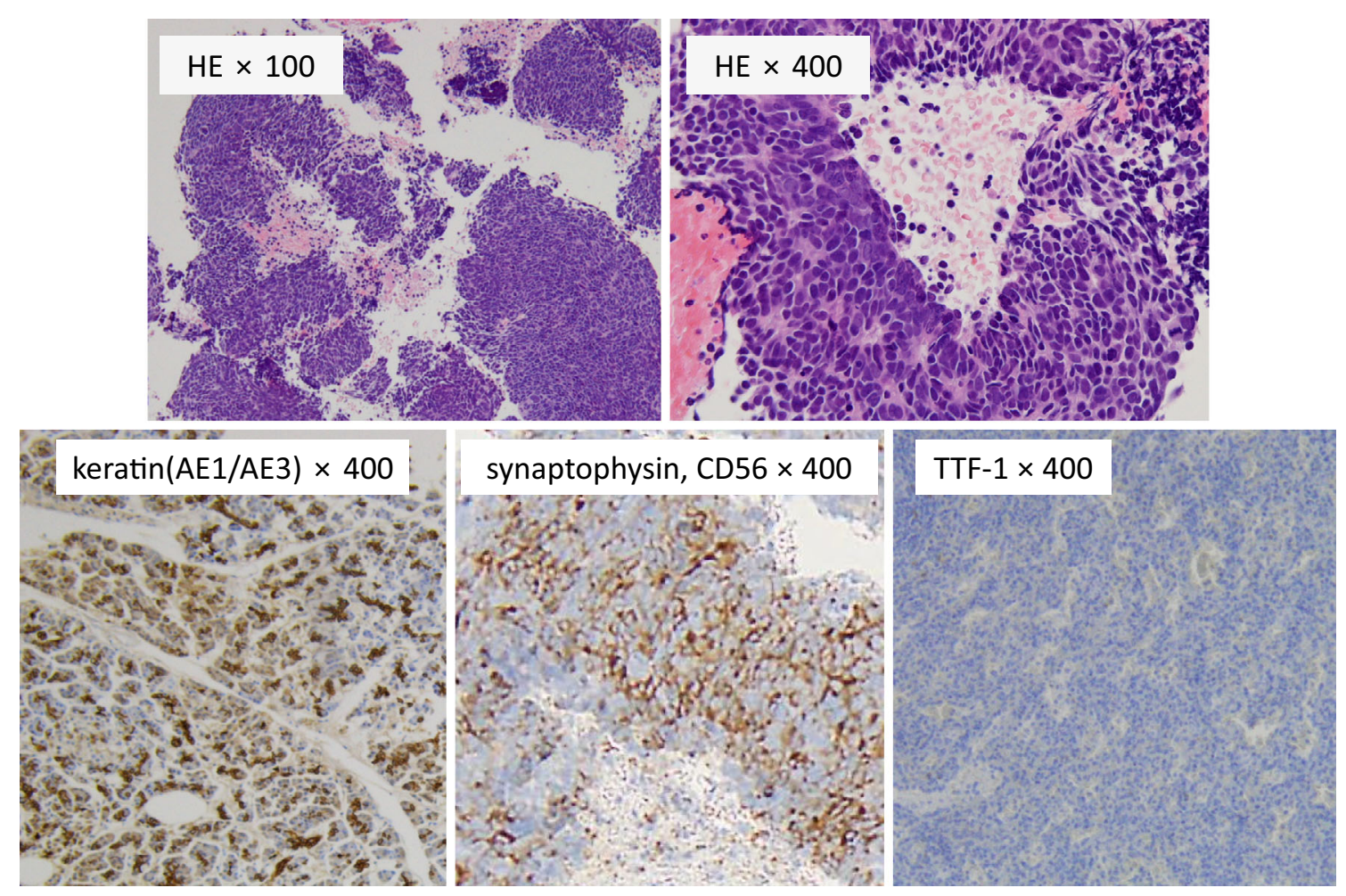

Figure 3. Histology of a mediastinal lymph node.

ach, colon, liver, kidney, pancreas, prostate, or brain. Furthermore, stomach and colon cancers were not detected on gastroscopy and colonoscopy. Analyses of tumor markers showed the following: carcinoembryonic antigen, $1.2 \mathrm{ng} / \mathrm{mL}$ (normal, $<5 \mathrm{ng} / \mathrm{mL}$ ); carbohydrate antigen 19-9, $2.2 \mathrm{U} / \mathrm{mL}$ (normal, <37 U/mL); cytokeratin 19 fragment, $1.82 \mathrm{ng} / \mathrm{mL}$ (normal, $<2.08 \mathrm{ng} / \mathrm{mL}$ ); squamous cell carcinoma antigen, $0.6 \mathrm{ng} / \mathrm{mL}$ (normal, $<2.0 \mathrm{ng} / \mathrm{mL}$ ); neuron specific $\gamma$-enolase, $83.7 \mathrm{ng} / \mathrm{mL}$ (normal, $<16.3 \mathrm{ng} / \mathrm{mL}$ ); and pro-gastrinreleasing peptide, $24.1 \mathrm{pg} / \mathrm{mL}$ (normal, $<81 \mathrm{pg} / \mathrm{mL}$ ). Biopsy of a mediastinal lymph node was performed by endoscopic ultrasound-guided fine needle aspiration (Fig. 3). The tumor cells were of a medium size and had a high nuclearcytoplasmic ratio, fine chromatin, and inconspicuous nucleoli. Immunohistochemically, the tumor cells were positive for cytokeratin (AE1/AE3), partially positive for synaptophysin and CD56, and negative for thyroid transcription factor 1. Based on these findings, lung neuroendocrine carcinoma (large cell neuroendocrine carcinoma [LCNEC] or small cell lung cancer [SCLC]; TxN3M0) was diagnosed. A cytological diagnosis of LCNEC or SCLC could not be made in our case, as SCLC is difficult to distinguish from LCNEC in some cases $(12,13)$. The final diagnosis was lung neuroendocrine carcinoma associated with dermatomyositis.

On Day 15, the dose of PSL was decreased to $55 \mathrm{mg} /$ day, and chemotherapy with carboplatin and etoposide was initiated. Chemotherapy was repeated monthly. The patient received four cycles of chemotherapy. Whether patients diagnosed with lung neuroendocrine carcinoma should be treated with non-SCLC (NSCLC)- or SCLC-based regimes remains unclear (14-16). Current treatment strategies for patients with lung neuroendocrine carcinoma are a mixture between the guidelines for NSCLC and SCLC patients (17). As we were unable to distinguish SCLC from LCNEC in our case, the patient was treated in accordance with the standard international protocol for SCLC $(17,18)$.

Within two weeks after starting chemotherapy, his muscle power had normalized, and the $\mathrm{CK}$ level had decreased to 54 IU/L. The MRC scale for muscle strength became grade 5 for the upper and lower limb muscles. The cutaneous manifestations were improved two months after starting chemotherapy. The swelling in the mediastinum lymph nodes also disappeared two months after starting chemotherapy (Fig. 2). PSL was successfully tapered to $15 \mathrm{mg} /$ day after 3 months and $10 \mathrm{mg} /$ day after 6 months. No complications associated with immunosuppression were identified during the clinical course. As of the time of writing, 5 months after completion of chemotherapy, the patient is continuing to receive $7 \mathrm{mg} /$ day of PSL.

\section{Systemic review}

We conducted a systemic review of the Medline database through the PubMed website of articles published from January 1947 to December 2015 using a combination of the following terms: "dermatomyositis", "small cell lung", and "lung neuroendocrine". Non-English articles were excluded. We identified a total of 60 English full-text articles using these search terms, including 16 cases of dermatomyositis associated with lung neuroendocrine tumor (large cell neuroendocrine carcinoma or small cell lung cancer). 
Table. Dermatomyositis Associated with Lung Neuroendocrine Carcinoma.

\begin{tabular}{|c|c|c|c|c|c|c|}
\hline Reference & Age / Sex & Diagnosis & Initial treatments & $\begin{array}{c}\text { Response: } \\
\text { cutaneous } \\
\text { manifestations }\end{array}$ & $\begin{array}{c}\text { Response: } \\
\text { muscular } \\
\text { manifestations }\end{array}$ & Final outcome \\
\hline 20 & $55 / \mathrm{M}$ & SCLC & None & N.S. & N.S. & Dead \\
\hline 21 & $44 / \mathrm{M}$ & SCLC & PSL (60 mg), chemotherapy & $\begin{array}{l}\text { Gradual } \\
\text { improvement }\end{array}$ & $\begin{array}{l}\text { Gradual } \\
\text { improvement }\end{array}$ & Dead \\
\hline 22 & $47 / \mathrm{M}$ & SCLC & N.S. & N.S. & N.S. & N.S \\
\hline 23 & $67 / \mathrm{M}$ & SCLC & Chemotherapy & $\begin{array}{c}\text { Dramatic } \\
\text { improvement }\end{array}$ & $\begin{array}{c}\text { Dramatic } \\
\text { improvement }\end{array}$ & N.S \\
\hline 24 & $58 / \mathrm{F}$ & SCLC & PSL, azathioprine & $\begin{array}{c}\text { Dramatic } \\
\text { improvement }\end{array}$ & $\begin{array}{c}\text { Dramatic } \\
\text { improvement }\end{array}$ & N.S \\
\hline 25 & $68 / \mathrm{F}$ & SCLC & $\begin{array}{l}\text { PSL, chemotherapy, } \\
\text { radiotherapy }\end{array}$ & N.S. & N.S. & Dead \\
\hline 26 & $65 / \mathrm{M}$ & SCLC & Chemotherapy & N.S. & No improvement & Dead \\
\hline 27 & $55 / \mathrm{F}$ & SCLC & $\begin{array}{l}\text { Surgery, chemotherapy } \\
\text { radiotherapy }\end{array}$ & Improvement & Improvement & Alive \\
\hline 28 & $74 / \mathrm{F}$ & SCLC & Radiotherapy, chemotherapy & N.S. & N.S. & Dead \\
\hline 29 & $60 / \mathrm{M}$ & SCLC & $\begin{array}{l}\text { PSL, chemotherapy, } \\
\text { radiotherapy }\end{array}$ & $\begin{array}{l}\text { Significant } \\
\text { improvement }\end{array}$ & $\begin{array}{l}\text { Significant } \\
\text { improvement }\end{array}$ & Dead \\
\hline 30 & $57 / \mathrm{M}$ & SCLC & IVIg & $\begin{array}{c}\text { Rapid } \\
\text { improvement }\end{array}$ & No improvement & Dead \\
\hline 31 & $79 / \mathrm{M}$ & SCLC & PSL, IVIg & Improvement & Improvement & Dead \\
\hline 32 & $62 / \mathrm{M}$ & SCLC & Steroid & Relieved & N.S. & N.S \\
\hline 33 & $52 / \mathrm{F}$ & SCLC & PSL $\rightarrow$ chemotherapy & N.S. & $\begin{array}{c}\text { Rapid } \\
\text { improvement }\end{array}$ & Alive \\
\hline 34 & $52 / \mathrm{M}$ & SCLC or LCNEC & PSL $\rightarrow$ chemotherapy & $\begin{array}{l}\text { Gradual } \\
\text { improvement }\end{array}$ & $\begin{array}{l}\text { Gradual } \\
\text { improvement }\end{array}$ & Dead \\
\hline 35 & $62 / \mathrm{M}$ & SCLC & PSL $\rightarrow$ chemotherapy & $\begin{array}{c}\text { Marked } \\
\text { improvement }\end{array}$ & $\begin{array}{c}\text { Marked } \\
\text { improvement }\end{array}$ & Alive \\
\hline Our case & $75 / \mathrm{M}$ & SCLC or LCNEC & PSL $\rightarrow$ chemotherapy & $\begin{array}{c}\text { Gradual } \\
\text { improvement }\end{array}$ & $\begin{array}{c}\text { Rapid } \\
\text { improvement }\end{array}$ & Alive \\
\hline
\end{tabular}

M: male, F: female, SCLC: small cell lung cancer, PSL: predonisolone, N.S.: Not specified, LCNEC: large cell neuroendocrine carcinoma, IVIg: intravenous, immunoglobulin

\section{Discussion}

Dermatomyositis is associated with various types of malignancy. However, the association of dermatomyositis with lung neuroendocrine carcinoma is rare. We herein report a case of dermatomyositis with lung neuroendocrine carcinoma. Dermatomyositis associated with malignancy is generally more resistant to corticosteroids than idiopathic dermatomyositis (19). In some cases, removal of the coexisting malignancy reportedly improves dermatomyositis and/or achieves good response to corticosteroids (19). However, whether the association of dermatomyositis with lung neuroendocrine carcinoma results in resistance to corticosteroids is still unclear. To analyze the published evidence, we conducted a systemic review, identifying 16 cases of dermatomyositis associated with lung neuroendocrine tumor (SCLC or LCNEC) reported as English full-text articles (Table) (20-35). Seven cases had been treated with chemotherapy, radiotherapy, and/or surgery for an existing tumor (21, 23, 25-29). Another four cases had been treated with corticosteroids alone or corticosteroids prior to chemotherapy (32-35), one case with corticosteroids and azathioprine (24), one case with intravenous immunoglobulin (IVIg) alone (30), and one case with corticosteroids and IVIg (31). No information about treatment was available for the remaining two reports.

In most cases, the symptoms of dermatomyositis improved even though the final prognosis was poor due to the underlying malignancy. Interestingly, both Labinjoh et al. 
and Albert et al. reported cases of dermatomyositis with SCLC that showed a prompt response to corticosteroids before chemotherapy $(33,35)$. Chao et al. reported a case of dermatomyositis with SCLC that showed a response to corticosteroids without chemotherapy (32). Murakami et al. reported a case of dermatomyositis with lung neuroendocrine carcinoma (SCLC or LCNEC) that showed a gradual response to corticosteroids before chemotherapy (34). Antonioli et al. reported a case of dermatomyositis with SCLC that showed a response to the combination of corticosteroids and IVIg (31). In our case, the patient's muscle weakness and dysphagia improved with corticosteroid therapy before chemotherapy, although the cutaneous and muscular manifestations were further improved after chemotherapy. Notably, administration of PSL improved the patient's oral intake and normalized the CK levels before the start of chemotherapy.

Given these present findings, while the efficacy of corticosteroids alone in treating dermatomyositis associated with lung neuroendocrine tumor is yet to be confirmed, corticosteroids prior to chemotherapy may be an option for improving the performance status of a patient, even if the patient has little chance of curing the associated cancer.

All of the procedures performed in the studies involving human participants were conducted in accordance with the ethical standards of the institutional committee and with the 1964 Declaration of Helsinki and its later amendments.

Informed consent was obtained from the participant described in the study.

The authors state that they have no Conflict of Interest (COI).

\section{References}

1. Sigurgeirsson B, Lindelöf B, Edhag O, Allander E. Risk of cancer in patients with dermatomyositis or polymyositis. A populationbased study. N Engl J Med 326: 363-367, 1992.

2. Hill CL, Zhang Y, Sigurgeirsson B, et al. Frequency of specific cancer types in dermatomyositis and polymyositis: a populationbased study. Lancet 357: 96-100, 2001.

3. Stockton D, Doherty VR, Brewster DH. Risk of cancer in patients with dermatomyositis or polymyositis, and follow-up implications: a Scottish population-based cohort study. Br J Cancer 85: 41-45, 2001.

4. Buchbinder R, Forbes A, Hall S, Dennett X, Giles G. Incidence of malignant disease in biopsy-proven inflammatory myopathy. A population-based cohort study. Ann Intern Med 134: 1087-1095, 2001.

5. Azuma K, Yamada H, Ohkubo M, et al. Incidence and predictive factors for malignancies in 136 Japanese patients with dermatomyositis, polymyositis and clinically amyopathic dermatomyositis. Mod Rheumatol 21: 178-183, 2011.

6. Fang YF, Wu YJ, Kuo CF, Luo SF, Yu KH. Malignancy in dermatomyositis and polymyositis: analysis of 192 patients. Clin Rheumatol 35: 1977-1984, 2016.

7. Zhang W, Jiang SP, Huang L. Dermatomyositis and malignancy: a retrospective study of 115 cases. Eur Rev Med Pharmacol Sci 13:
77-80, 2009.

8. Liu WC, Ho M, Koh WP, et al. A 11-year review of dermatomyositis in Asian patients. Ann Acad Med Singapore 39: 843-847, 2010.

9. Teoh JW, Yunus RM, Hassan F, Ghazali N, Abidin ZA. Nasopharyngeal carcinoma in dermatomyositis patients: A 10-year retrospective review in Hospital Selayang, Malaysia. Rep Pract Oncol Radiother 19: 332-336, 2014.

10. Bohan A, Peter JB. Polymyositis and dermatomyositis (first of two parts). N Engl J Med 292: 344-348, 1975.

11. Bohan A, Peter JB. Polymyositis and dermatomyositis (second of two parts). N Engl J Med 292: 403-407, 1975.

12. Travis WD. Update on small cell carcinoma and its differentiation from squamous cell carcinoma and other non-small cell carcinomas. Mod Pathol 25: S18-S30, 2012.

13. Hiroshima K, Iyoda A, Shida T, et al. Distinction of pulmonary large cell neuroendocrine carcinoma from small cell lung carcinoma: a morphological, immunohistochemical, and molecular analysis. Mod Pathol 19: 1358-1368, 2006.

14. Sun JM, Ahn MJ, Ahn JS, et al. Chemotherapy for pulmonary large cell neuroendocrine carcinoma: similar to that for small cell lung cancer or non-small cell lung cancer? Lung Cancer 77: 365370, 2012.

15. Iyoda A, Makino T, Koezuka S, Otsuka H, Hata Y. Treatment options for patients with large cell neuroendocrine carcinoma of the lung. Gen Thorac Cardiovasc Surg 62: 351-356, 2014.

16. Varlotto JM, Medford-Davis LN, Recht A, et al. Should large cell neuroendocrine lung carcinoma be classified and treated as a small cell lung cancer or with other large cell carcinomas? J Thorac Oncol 6: 1050-1058, 2011.

17. National Comprehensive Cancer Network. NCCN Clinical Practice Guidelines in Oncology: small cell lung cancer. Version 2. [cited 2016 Apr 10] Available from: https://www.tri-kobe.org/nccn/guideli ne/lung/english/small.pdf

18. Schmittel A, Fischer von Weikersthal L, Sebastian M, et al. A randomized phase II trial of irinotecan plus carboplatin versus etoposide plus carboplatin treatment in patients with extended disease small-cell lung cancer. Ann Oncol 17: 663-667, 2006.

19. Carsons $S$. The association of malignancy with rheumatic and connective tissue diseases. Semin Oncol 24: 360-372, 1997.

20. McCombs RP, MacMahon HE. Dermatomyositis associated with metastasizing bronchogenic carcinoma. A clinicopathological conference. Med Clin North Am 31: 1148-1162, 1947.

21. Williams RT. Carcinoma of the bronchus with hyponatraemia and dermatomyositis. BMJ 1: 233-236, 1963.

22. Lightman NI, Shield L, Siegelman SS. Neuromuscular disease and the chest. JAMA 238: 2638-2640, 1977.

23. Fairlamb D, Boesen E. Gynaecomastia associated with gonadotrophin-secreting carcinoma of the lung. Postgrad Med J 53: 269-271, 1977.

24. Rose JD. Membranous glomerulonephritis, dermatomyositis, and bronchial carcinoma. BMJ 2: 641, 1979.

25. Chee YC. Small cell carcinoma of lung: a prospective clinical study. Ann Acad Med Singapore 14: 450-456, 1985.

26. Sakuragi T, Oshita F, Nagashima S, et al. Retrospective analysis of the treatment of patients with small cell lung cancer showing poor performance status. Jpn J Clin Oncol 26: 128-133, 1996.

27. Mori H, Habe K, Hakamada A, Isoda K, Mizutani H. Relapse of dermatomyositis after 10 years in remission following curative surgical treatment of lung cancer. J Dermatol 32: 290-294, 2005.

28. Lee WY, Kastelik J, Campbell A, Avery G, McGivern D, Lind M. A case report of dermatomyositis associated with small cell lung cancer. Tumori 98: 158e-161e, 2012.

29. Nikolaos T, Maria T, Ioannis KD, et al. Dematomyositis as an early manifestation and a significant clinical precursor of lung cancer: report of a rare case and review of the current literature. 
Int J Clin Exp Med 6: 105-109, 2013.

30. Zangrilli A, Papoutsaki M, Bianchi L, Teoli M, Chimenti S. Bullous dermatomyositis: a marker of poor prognosis and aggressive internal malignancy? Acta Derm Venereol 88: 393-394, 2008.

31. Antonioli CM, Airò P. Dermatomyositis associated with lymphoproliferative disorder of NK cells and occult small cell lung carcinoma. 23: 239-241, 2004.

32. Chao G, Fang L, Lu C, Chen Z. Small cell lung cancer presenting as dermatomyositis: mistaken for single connective tissue disease. Rheumatol Int 32: 1737-1740, 2012.

33. Labinjoh C, Selby C. Dermatomyositis associated with small cell carcinoma of the lung: dramatic response to corticosteroid therapy. Respir Med 92: 601-606, 1998.
34. Murakami Y, Kanazawa K, Okuno K, et al. High-grade neuroendocrine carcinoma of the lung presenting an unusual spread mimicking pleural mesothelioma associated with dermatomyositis. Am J Med Sci 327: 227-230, 2004.

35. Albert TJ, Bastawrous S, Raugi GJ, Hirschmann JV. A 62-year-old man with skin rash and an abnormal chest radiograph. Chest 147: e90-e94, 2015.

The Internal Medicine is an Open Access article distributed under the Creative Commons Attribution-NonCommercial-NoDerivatives 4.0 International License. To view the details of this license, please visit (https://creativecommons.org/licenses/ by-nc-nd/4.0/).

(C) 2017 The Japanese Society of Internal Medicine http://www.naika.or.jp/imonline/index.html 